\section{5. 鉤歯の挙動に関する研究}

\section{第 1 報 RPA，RPI および Aker's 鉤の比較}

\section{○守川 雅雄・迫 雅裕・森山 茂美 鱒見 進一・豊田 静夫}

小園凱夫 (九粜大・理工)

局部義歯学における最重要関心事の一つである“各種 デザインによる維持歯に与える影響”を調べるため，従 来からストレンゲージ法, 光弾性法, 有限要素法など種 々の方法があるが，それぞれに一長一短があり確定的な 方法はまだ確立されていない，そてで演者らはキネジオ を用いて荷重下に抢ける銁菌の変位を解析する新しい方 法を考案した。これによると，対象となる物体の挙動を 任意の拡大倍率（本実験では300倍拡大）で三次元的に かつ動態として把握, 解析できる.今回はこの方法によ り RPI，ならびにそれをモディファイドした RPA お よび Aker's を用い，義茵の荷重下における鈎崡の挙 動のちがいを比較，検討したところ次の結論を得た。な お実験は Kennedy class II 症例に片側性に設計した義 㐘を用い，シュミレーターモデル上で行った。

1.RPA は Aker's とほほ同じ動きがみられた。

2. 加重下では，ほとんどのクラスプにおいて近心傾 斜がみられた。

3. 緩圧作用により, 鉤歯の動きは最小になる筈の RPI（krol）において最も広範な動きが観察され た.

4.RPI において, 舌側からの力に対する対応の必 要性が考えられた。

5. キネジオによる観察方法の有効性が確認された. 本測定方法は鉤歯の挙動はもとより，鉤歯と義歯，ま た義嵝構成要素間の力学的検討が容易に行えるばかりで なく，直接生体に用いての観察も可能であろうと考えら れる. 従って, 今後ての方法を用いて, あるいは光弾性 法, ストレンゲージ法と併用して, 従来十分な解析が加 えられているとは言えない，ての分野における数多くの 問題を手がけていくつもりでいる.

\section{9. アルギン酸印象材の固定効果について}

第 2 報 固定液の濃度, 浸濆時間および歯型材との 関係

$\begin{array}{rlc}\text { ○城戸 } & \text { 寛史・守川 } & \text { 雅雄・阿部 伸朗 } \\ \text { 豊田 } & \text { 静夫 } & \text { (九歯大・ } 1 \text { 補経) } \\ \text { 田島 } & \text { 清司 } & \text { (九崡大・理工) }\end{array}$

アルギン酸印象材は, 臨床において最も多用されてい る.しかしシネレシスのために経時的な安定性に久け， 注入した模型材と未反応のアルギン酸塩が反応して模型 表面を粗造にすると言われている。乙れらの好ましくな い反応を防止するために，従来から $\mathrm{K}_{2} \mathrm{SO}_{4}, \mathrm{ZnSO}_{4}$, $\mathrm{KAI}\left(\mathrm{SO}_{4}\right)^{2}$ などの $1 \sim 2 \%$ 水溶液に数分間浸漬するこ とが推奖され，成書の多くにも記載されている.しか し, 各アルギン酸印象材の使用説明書に固定の必要性の 有無を明示したものも無く，現在では，アルジートの 離槳の影響を防止するために $\mathrm{ZnF}_{2}$ を加えたものもあ り，固定の必要性はないと言う人もあるなど非常に曖昧 である。

今回は，印象材としてハイテクニコール (而至社製)， 模型材として普通石膏（サンエス石高株式会社製），硬 石育（プラストーン・而至社製）を用い，固定液として $\mathrm{K}_{2} \mathrm{SO}_{4}(1 \%, 3 \%, 5 \%)$ に 1 分，3 分，5 分浸漬さ せた試料を製作し, 表面粗さ, 表面硬さおよび走査型電 子顕微鏡によって，アルギン酸印象における固定液の効 果について検討した結果, 次の結論を得た。

1) 全ての試料において, 水, 固定液とも5 分間浸漬 したものがもっとも大きい表面粗さを示した．

2) 硬石育においては, 普通石膏より大きい表面粗さ を示した。

3 ）硬石膏においては，3\%固定後に 3 分間浸漬した 試料, 普通石膏においては $1 \%$ 固定液に 1,3 分間浸漬 した試料で変面荒れが最も小さかった。

4 ）表面硬さにおよぼす固定液の效果は認められなか った。

最も多用されているこのアルギン酸印象材をより有效 に使用するために, 今後, さらに多くの印象材と模型材 抢よび固定液，それぞれの組合せを変えて実験を行うつ もりである。 